\title{
Pendekatan Pendidikan Matematika Realistik Berbasis Open Ended Terhadap Kemampuan Pemecahan Masalah Matematika Siswa
}

\author{
${ }^{*}$ Ni P. Rizky Wulandari'1 , N. Dantes ${ }^{2}$, P. Aditya Antara ${ }^{3}$ \\ ${ }^{1}$ Prodi PGSD, Jurusan Pendidikan Dasar, FIP Universitas Pendidikan Ganesha, Singaraja, Indonesia \\ 2 Prodi BK, Jurusan Ilmu Pendidikan Psikologi dan Bimbingan, FIP, Universitas Pendidikan Ganesha, Singaraja, Indonesia \\ ${ }^{3}$ Prodi PG PAUD, Jurusan Pendidikan Dasar ,FIP, Universitas Pendidikan Ganesha, Singaraja, Indonesia
}

\section{A R T I C L E I N F O}

Article history:

1 Maret 2020 Received in revised form

30 Maret 2020

Accepted 11 April 2020

Available online 15

Mei 2020

Kata Kunci:

Pemecahan Masalah, Open

Ended, Matematika

Keywords:problem solving Open-Ended, Mathematic

\begin{abstract}
A B S T R A K
Rendahnya kemampuan pemecahan masalah matematika menjadi permasalahan utama penelitian ini. Hal tersebut disebabkan kurangnya pendekatan pembelajaran yang efektif yang masih terpusat pada guru. Penelitian ini bertujuan untuk mengetahui pengaruh Pendekatan Pendidikan Matematika Realistik Berbasis Open Ended terhadap Kemampuan Pemecahan Masalah Matematika Siswa Kelas V di Gugus $\mathrm{V}$ Kecamatan Buleleng. Jenis penelitian adalah eksperimen semu dengan rancangan non equivalen post test only control group design. Populasi penelitian adalah siswa kelas V SD di Gugus V Kecamatan Buleleng berjumlah 122 orang. Sampel penelitian adalah SDN 1 Petandakan sebagai kelompok eksperimen dan SDN 1 Nagasepaha sebagai kelompok kontrol, dengan random sampling teknik intact group. Data kemampuan pemecahan masalah dikumpulkan menggunakan instrumen tes berupa esai dengan jumlah pernyataan sebanyak 10 butir
\end{abstract} soal open ended. Data dianalisis menggunakan analisis statistik deskriptif dan statistik inferensial (ujit). Berdasarkan analisis data, didapat $t_{\text {hitung }}$ lebih besar dari $t_{\text {tabel }}(13,30>1,68)$ sehingga $H_{0}$ ditolak dan $\mathrm{H}_{1}$ diterima. Berdasarkan hasil penelitian dapat disimpulkan Pendekatan Pendidikan Matematika Realistik Berbasis open-ended berpengaruh terhadap Kemampuan Pemecahan Masalah Matematika Siswa Kelas V di Gugus V Kecamatan Buleleng.

\begin{abstract}
A B S T R A C T
The low ability to solve mathematic problems was the main problem on this research. That was due to the lack of an effective learning approach that was still centered on the teacher. The aim of this research was to determine the effect of Mathematics Realistic Education approach based Open Ended toward the Mathematic Problem Solving Capability on fifth grade students in Cluster V, Buleleng District. The type of this research was a quasi-experimental design with a non-equivalent post test only control group design. The research population was on fifth grade elementary students in Cluster V, Buleleng District which was consisted of 122 students. The research sample was SD N 1 Petandakan as the experimental group and SD N 1 Nagasepaha as the control group, with a random sampling intact group technique. Data of problem-solving ability was collected using instrument test in the form of essays with the number of statements of 10 open ended questions. Data were analyzed by using descriptive statistics analysis and inferential statistics (t-test). Based on data analysis showed that the $t_{\text {count }}$ was higher than $t_{\text {table }}(13.30>1.68)$ so $H O$ was rejected and $H 1$ was accepted. Based on the results of this research, it could be concluded that the Mathematics Realistic Education approach based Open Ended had an effect toward the Mathematic Problem Solving Capability on fifth grade students in Cluster V, Buleleng District.
\end{abstract}

\section{Pendahuluan}

Matematika sebagai salah satu mata pelajaran di sekolah memiliki ilmu yang berperan penting dalam kehidupan sehari-hari untuk meningkatkan kemampuan siswa. Pembelajaran matematika yang didapatkan siswa di sekolah dasar merupakan dasar bagi penerapan konsep matematika pada jenjang pendidikan siswa berikutnya. Pengetahuan matematika harus dikuasai sedini mungkin oleh para

Copyright (C) Universitas Pendidikan Ganesha. All rights reserved

Corresponding author

E-mail addresses: puturizkywulan@gmail.com (Rizky) ${ }^{1}$, dantes@undiksha.ac.id(Dantes)²,

putuaditya.antara@undiksha.ac.id(Aditya) ${ }^{3}$ 
siswa dan pembelajaran matematika di sekolah agar mampu mengembangkan potensi yang dimiliki siswa, sehingga mereka mampu memahami pembelajaran matematika dengan benar (Danic, Japa, \& Diputra, 2019).

Pembelajaran matematika di sekolah dasar memiliki beberapa tujuan untuk mencapai hasil yang diharapkan. Tujuan pembelajaran matematika bukan hanya agar siswa mampu menyelesaikan soal-soal rutin matematika (soal ulangan harian, ujian semester, ujian nasional, maupun ujian masuk ke jenjang yang lebih tinggi). Namun tujuan pembelajaran matematika harus diarahkan kepada tujuan yang lebih komprehensif, sesuai dengan tuntutan kurikulum (Kamarullah, 2017) yaitu: (1) Memahami konsep matematika, menjelaskan keterkaitan antar konsep dan mengaplikasikan konsep atau algoritma, secara luwes, akurat, efisien, dan tepat, dalam pemecahan masalah; (2) Menggunakan penalaran pada pola dan sifat, melakukan manipulasi matematika dalam membuat generalisasi, menyusun bukti, atau menjelaskan gagasan dan pernyataan matematika; (3) Memecahkan masalah yang meliputi kemampuan memahami masalah, merancang model matematika, menyelesaikan model dan menafsirkan solusi yang diperoleh; (4) Mengkomunikasikan gagasan dengan simbol, tabel, diagram, atau media lain untuk memperjelas keadaan atau masalah; (5) Memiliki sikap menghargai kegunaan matematika dalam kehidupan, yaitu memiliki rasa ingin tahu, perhatian, dan minat dalam mempelajari matematika, serta sikap ulet dan percaya diri dalam pemecahan masalah. Dengan demikian, salah satu tujuan pembelajaran matematika di sekolah dasar yang utama adalah bertujuan agar siswa dapat memecahkan masalah. Mata pelajaran matematika diberikan kepada siswa agar mereka mampu berpikir kritis, memiliki kemampuan pemecahan masalah, dapat bekerja sama, dan mempunyai kreatifitas (Muchlis, 2012).

Pentingnya pemecahan masalah dalam pembelajaran matematika, tidak terlepas dengan suatu masalah yang diberikan oleh guru (Sa'o, 2016). Menurut Antara (2019), guru melaksanakan pembelajaran dengan melaksanakan fungsi guru sebagai teladan, fasilitator dan motivator kepada siswa. Sehingga, guru memfasilitasi siswa agar dapat memecahkan masalah matematika. Pada permasalahan yang diberikan, siswa tidak hanya berfokus pada bagaimana cara berhitung tetapi juga bagaimana cara untuk dapat memecahkan suatu masalah (problem solving). Pengajaran guru dalam kelas merupakan hal yang penting karena dengan pengajarannya dapat menentukan apakah siswa mampu memecahkan masalah yang ada atau tidak. Setiap permasalahan yang diberikan akan selalu terdapat cara yang digunakan untuk memecahkan masalah. Pemecahan masalah dimiliki setiap orang yang nantinya digunakan siswa dalam mengaplikasikan konsep ke dalam kehidupan sehari- hari (Gunantara, dkk, 2014). Sehingga, ketika peserta didik sudah mampu menyelesaikan permasalahan maka di dalam dirinya sudah memiliki potensi atau dalam menyelesaikan masalah yang dihadapinya secara nyata.

Permasalahan yang baik diberikan kepada siswa yakni permasalahan open ended atau disebut permasalahan terbuka. Open ended dapat disebut sebagai soal tidak rutin. Hal ini juga disampaikan Hartono (2014), soal tidak rutin dapat diselesaikan dengan mengunakan pemahaman yang diperoleh siswa secara langsung. Siswa-siswi perlu memiliki kemampuan pemecahan masalah sesuai dalam kurikulum matematika di sekolah. Masalah dalam matematika merupakan kesempatan yang baik untuk dapat mengembangkan sikap positif, dan kemampuan untuk menyelesaikan masalah matematika. Dengan memecahkan masalah open-ended siswa dapat menuangkan idenya secara bebas tanpa campur tangan dari guru, sehingga peran aktif siswa dapat terlihat (Hidayat \& Sariningsih, 2018).

Menurut Kamarullah (2017), kemampuan pemecahan masalah di Indonesia masih lemah. Kemampuan matematika peserta didik Indonesia telah diuji dalam berbagai ajang kompetisi Internasional salah satunya didapatkan TIMSS (Trend in International Mathematics and Science Study). TIMSS adalah studi internasional tentang kecenderungan atau arah dan perkembangan matematika dan sains. Studi ini diselenggarakan oleh International Association for the Evaluation of Educational Achievement (IEA). TIMSS 2015 Indonesia berada di peringkat 44 dari 49 negara. Sependapat dengan hal tersebut Hadi (2017) berpendapat bahwa "Data menunjukkan bahwa nilai rerata dalam ujian akhir nasional selalu di bawah 5, senada dengan kompetesi interasioal seperti IMO (International Mathematics Olympiad) siswa Indonesia menjukkan kinerja yang rendah". Dengan demikian, kemampuan pemahaman dan pemecahan masalah matematika belum optimal. Pembelajaran matematika di sekolah lebih banyak berfokus pada pencapaian target materi, sehingga konsekuesinya siswa tidak paham dengan materi. Siswa tidak membangun sendiri pengetahuan yang berkaitan dengan konsep matematika, tetapi cenderung menghafalkan rumus-rumus dan konsep pada matematika tanpa mengetahui makna sesungguhnya.

Permasalahan tersebut juga terjadi di Gugus V Kecamatan Buleleng. Berdasarkan hasil wawancara yang dilakukan tanggal 18-25 Oktober 2019 dengan guru kelas V SD di Gugus V Kecamatan Buleleng diperoleh informasi bahwa guru sudah melakukan/menerapkan beberapa model pembelajaran tetapi proses pembelajaran masih terdapat beberapa kendala, yaitu 1) dalam penyampaian pembelajaran masih terpusat pada guru (teachered centered) sehingga siswa kurang aktif pemahaman dan kemampuan siswa tidak digali di dalam dirinya sendiri, 2) pemahaman tentang konsep matematika seutuhnya hanya 
diberikan oleh guru saja. Dalam pembelajaran guru seolah-olah mentransfer pemahaman kepada siswa, 3) guru mengejar target tercapainya semua materi pembelajaran, 4) kemampuan kognitif siswa berbedabeda, 5) kemampuan pemecahan masalah matematika yang masih kurang.

Dalam observasi juga tanpak masalah yang tidak jauh berbeda yakni seperti, 1) siswa hanya memakai rumus yang sudah diberikan guru sesuai dengan contoh permasalahan yang telah diberikan guru, 2) guru juga masih terfokus pada buku ajar yang dipegang, sehingga dalam pemberian soal maupun masalah-masalah guru hanya mengambil masalah yang ada di buku paket tanpa mengembangkan permasalahan yang ada di kenyataan siswa. Sehingga, proses pembelajaran di kelas kurang mampu mengaitkan dengan kehidupan sehari-hari. Kesulitan peserta didik dalam pembelajaran juga dapat dikarenakan siswa hanya diberikan soal rutin, sehingga saat diberikan soal non rutin siswa belum terlatih dalam memecahkan masalah. Dalam hal ini, guru hanya memberikan masalah rutin. Masalah rutin ini adalah masalah yang sering ditemui dan terdapat di dalam buku pelajaran, maupun LKS siswa. Sehingga, kemampuan pemecahan masalah siswa terbatas hanya pada soal rutin saja. Berdasarkan data pencatatan hasil belajar matematika siswa melalui nilai UTS, dari 5 SD yang terdapat di Gugus V Kabupaten Buleleng tersebut terdapat 71 siswa Belum Tuntas. Hampir semua SD di gugus ini memiliki mayoritas rata-rata nilai UTS masih di bawah nilai KKM dan juga banyak terlihat siswa yang Belum Tuntas daripada siswa yang Tubntas. Dapat dilihat dari 122 siswa terdapat 51 orang sudah mencapai KKM dan 71 orang belum mencapai KKM. Data tersebut merupakan suatu masalah yang harus diatasi agar pemahaman belajar siswa menjadi lebih baik. Permasalahan tersebut terjadi karena siswa tidak memahami masalah yang disajikan pada soal. Banyak siswa yang tidak mampu menyelesaikan soal open ended yang sederhana. Hal tersebut dikarenakan guru jarang memberikan soal-soal nonrutin, sehingga ketika siswa dihadapkan pada soal-soal nonrutin maka siswa mengalami kesulitan untuk menyelesaikannya

Berdasarkan permasalahan-permasalahan yang ditemukan dari wawancara, pengamatan dan juga studi dokumen yang dilakukan di SD Gugus V Kabupaten Buleleng, maka diperlukan suatu pembelajaran untuk mengoptimalkan kemampuan pemecahan masalah matematika. Sehingga mampu menguasai pembelajaran dan memiliki kemampuan pemecahan masalah matematika untuk menyelesaikan permasalahan matematika dengan baik. Kemampuan pemecahan masalah (problem solving) siswa dapat dikembangkan dengan jalan menggunakan model/pendekatan yang inovatif dan memberi kesempatan siswa untuk lebih aktif beraktivitas dan berpartisipasi dalam proses pembelajaran. Beberapa langkah untuk mencapai pemecahan masalah menurut Polya (dalam Amir, 2015) yakni: a) pemahaman masalah; b) merencanakan strategi penyelesaian; c) Melaksanakan strategi penyelesaian; d) Meninjau jawaban. Langkah tersebut saling berkaitan dalam memperoleh kemampuan pemecahan masalah.

Salah satu pendekatan yang memberikan kesempatan siswa memecahkan masalah secara aktif adalah pendekatan Pendidikan Matematika Realistik (PMR) Berbasis Open Ended. Pendekatan Pendidikan Matematika Realistik telah dikenal di dunia dengan sebutan Realistic Mathematics Education (RME). Menurut Hadi (2017), menyatakan bahwa pendekatan yang menjanjikan dalam pembelajaran matematika adalah Pendidikan Matematika Realistik (PMR). Sehingga, PMR dapat meningkatkan kemampuan pemecahan masalah pada pembelajaran matematika. PMR adalah sebuah pendekatan untuk pendidikan matematika yang melibatkan siswa mengembangkan pemahaman mereka dengan mengeksplorasi dan memecahkan masalah yang ditetapkan dalam konteks yang terlibat ketertarikan siswa (Wibowo, 2017). Kurniadi (dalam Lestari \& Sofyan, 2014), mengemukakan bahwa kelebihan PMR antara lain yakni: Pertama yaitu PMR berpendekatan dengan bertujuan untuk membangkitkan pemahamannya sendiri akan masalah, sehingga siswa akan lebih mengingat. Kedua, pembelajaran bersifat menyenangkan peserta didik sehingga siswa lebih mudah menemukan penyelesaian permasalahan tanpa ada rasa takut dengan menggunakan permasalahan nyata. Ketiga, pembelajaran membuat siswa turut aktif dan terbuka terhadap pemahamannya. Keempat, proses pembelajaran dapat memupuk kerjasama dalam kelompok. Kelima, pembelajaran menemukan sendiri sehingga siswa dapat mempresentasikan hasil penyelesaiannya sendiri dan lebih mengasah keberanian. Keenam, dapat melatih siswa dalam mengemukakan pendapatnya. Ketujuh, secara tidak langsung pembelajaran dapat mendidik budi pekerti siswa. Kelebihan PMR lainnya yakni melibatkan siswa, maka pembelajaran tidak lagi menganut paradigma transfer to knowledge, sehingga berpartisipasi dalam pembelajaran.

Freudenthal (dalam Wijaya, 2012), menyatakan dalam PMR terdapat konsep kebermaknaan. Ketika pembelajaran tersebut bermakna, maka proses pembelajaran akan lebih mudah dipahami siswa, dan siswa lebih mengerti intisari dari pembelajaran. Karakteristik Pendidikan Matematika Realistik, yaitu guru harus mengusahakan agar sisa selalu aktif dalam pelajaran untuk merekontruksi pengetahuannya sendiri. Siswa harus diberikan kesempatan dalam pemecahan masalah matematika, sehingga pemahaman didapatkan oleh dirinya sendiri bukan hanya sekadar proses transfer ilmu. Dengan PMR, 
siswa akan mudah memaknai pembelajaran karena menggali sendiri pemahaman yang dimiliki untuk memecahkan masalah.

Pembelajaran matematika yang digunakan untuk memecahkan permasalahan seorang siswa maka memerlukan keterkaitan suatu konsep matematika. Menurut Skemp (dalam Mairing, 2018:13), suatu konsep-konsep yang terkait akan bermakna dalam pikiran siswa. Dalam hal ini, suatu konsep yang bermakna akan lebih lama bertahan di dalam pikiran siswa. Sebaliknya, yang tidak bermakna akan lebih mudah dan cepat dilupakan oleh seorang siswa. Sehingga, dalam permasalahan matematika dituntut agar seorang siswa dapat melakukan pengaitan antar konsep matematis sehingga konsep-konsep tersebut bermakna dalam pikiran siswa. Penanaman konsep pada siswa sangat penting dalam kemampuan pemecahan masalah. Kemampuan utama dalam mempelajari matematika yakni harus memiliki kemampuan dalam memecahkan masalah. Perlu dikembangkan keterampilan dalam menyelesaikan soal sehingga meningkatkan kemampuan dalam upaya meningkatkan pemecahan suatu permasalahan (Hidayat \& Sariningsih, 2018).

Masalah matematika akan bermakna yang diberikan kepada peserta didik selanjutya disajikan dengan permasalahan terbuka (open ended). Menurut Maulana (dalam Isrok'atun \& Rosmala, 2018), menyatakan masalah matematika dapat diberikan kepada siswa di awal pembelajaran, akhir, maupun di tenggah kegiatan suatu pembelajaran. Di dalam pembelajaran, ketika siswa diberikan permasalahan terbuka (open-ended) siswa dapat memiliki kemampuan pemecahan yang berbeda. Dengan demikian, siswa tersebut memiliki pemahaman tersendiri dan siswa akan mudah memahami konsep matematika.

Berdasarkan paparan di atas, dipandang perlunya dilakukan penelitian terkait untuk pemecahan masalah tersebut dengan upaya untuk meningkatkan kemampuan pemecahan masalah matematika dengan pendekatan pembelajaran kepada siswa. Pendekatan Pendidikan Matematika Realistik Berbasis Open-Ended diharap mampu meningkatkan kemampuan pemecahan masalah matematika siswa di kelas. Oleh karena itu, untuk mendapatkan gambaran yang jelas mengenai sejauh mana pengaruh Pendidikan Matematika Realistik Berbasis Open-Ended terhadap Kemampuan Pemecahan Masalah Matematika siswa, maka dilakukanlah penelitian yang berjudul "Pengaruh Pendekatan Pendidikan Matematika Realistik Berbasis Open-Ended terhadap Kemampuan Pemecahan Masalah Matematika Siswa Kelas V di Gugus V Kecamatan Buleleng Tahun Ajaran 2019/2020".

Berdasarkan uraian tersebut, maka penelitian ini bertujuan untuk mengetahui pengaruh yang signifikan implementasi Pendekatan Pendidikan Matematika Realistik Berbasis Open Ended Terhadap Kemampuan Pemecahan Masalah Matematika Siswa Kelas V di Gugus V Kecamatan Buleleng.

\section{Metode}

Penelitian ini dilakukan pada siswa kelas V SD di Gugus V Kecamatan Buleleng. Jenis penelitian yang dilakukan yakni eksperimen semu (quasi eksperiment). Penelitian Eksperimen semu merupakan penelitian yang paling sedikit dapat dilakukan dalam penelitian dimana satu kondisi yang dapat dimanipulasikan, sementara pada kondisi lainnya dianggap konstan dan juga perbedaan kondisi ataupun variabelnya dapat diukur. Ini berarti dalam kondisi kelompok eksperimen tidak semua variabel dapat dikontrol peneliti.

Penelitian ini menggunakan desain Non Equivalent Post-Test Only Control Group Design. Desain eksperimen menggunakan 2 kelompok. Pada kelompok eksperimen mendapat perlakuan khusus yaitu diberikan pendekatan Pendidikan Matematika Realistik berbasis open ended. Hal tersebut dilakukan untuk melihat perbedaan yang terdapat pada kelompok kontrol dan eksperimen khususnya pada aspek kemampuan pemecahan masalah dengan diberikannya post test. Namun, pada kelomok kontrol hanya dibelajarkan sesuai pembelajaran umumnya di sekolah. Adapun desain dalam penelitian ini secara umum seperti pada Tabel 1.

Tabel 1. Desain Non equivalent Post-test Only Control Group Design

\begin{tabular}{cccc}
\hline Kelas & Treatment & Post-T, \\
\hline $\mathrm{E}$ & $\mathrm{X}$ & 01 & \\
$\mathrm{~K}$ & - & 02 & \\
\hline
\end{tabular}

(dimodifikasi dari Dantes, 2017:16)

Keterangan:

E : : kelompok eksperimen

$\mathrm{K} \quad$ : kelompok kontrol

$\mathrm{X} \quad$ : perlakuan (treatment) dengan pembelajaran pendekatan PMR berbasis open-ended 
- $\quad$ : tidak mendapat perlakuan pendekatan PMR berbasis open-ended (saintifik)

01 : pengamatan akhir (post test) berupa kemampuan pemecahan masalah matematika kelompok eksperimen

02 : pengamatan akhir (post test) berupa kemampuan pemecahan masalah matematika kelompok pembanding (kontrol)

Semua objek/subjek yang memiliki karakteristik dan kuantitas yang dipelajari dan ditetapkan peneliti serta ditarik kesimpulannya disebut populasi (Sugiyono, 2017). Populasi dalam penelitian ini adalah seluruh kelas V SD di Gugus V Kecamatan Buleleng terdiri dari 5 SD, yaitu SD 1 Sari Mekar, SD 2 Sari Mekar, SD 1 Petandakan, SD 2 Petandakan, dan SD 1 Nagasepaha. Jumlah dari seluruh anggota populasi yaitu sebanyak 122 orang. Dalam populasi tersebut, dengan jumlah siswa yang berbeda dan juga kemampuan siswa kelas V pada setiap sekolah dasar beranekaragam sehingga dilakukannya uji kesetaraan. Data yang dianalisis yakni nilai Ulangan Tengah Semester mata pelajaran matematika siswa kelas V SD di Gugus V Kecamatan Buleleng. didapatkan harga $F_{\text {hitung }}=0,92$ dan $F_{\text {tabel }}$ (taraf signifikansi $5 \%$ ) dengan $\mathrm{db}_{\text {antar }}=4, \mathrm{db}_{\text {dalam }}=117$ didapatkan hasil 2,45. Dengan demikian, didapatkan bahwa $F_{\text {hitung }}<F_{\text {tabel }}$, sehingga $\mathrm{H}_{1}$ ditolak dan $\mathrm{H}_{0}$ diterima. Jadi, kemampuan siswa diantara SD tersebut dapat dikatakan setara.

Penelitian ini menggunakan teknik random sampling yakni intact group seluruh individu di dalam sampel ini utuh seperti kelas dimana randomisasi tidak dapat dilakukan (Dantes, 2012). Tidak memungkinkan bagi peneliti untuk melakukan pengacakan individu untuk membentuk dan menditribusikan pada kelas baru. Berdasarkan teknik random sampling yang dirandom adalah kelas sebagai sebagai intact group tersebut, SD N 1 Petandakan dengan jumlah siswa sebanyak 25 orang terpilih menjadi kelas eksperimen dengan mendapat perlakuan pembelajaran dengan pendekatan pendidikan matematika realistik (PMR) berbasis open-ended, sedangkan SD N 1 Nagasepaha dengan jumlah siswa sebanyak 25 siswa terpilih menjadi kelas kontrol dengan pembelajaran berlangsung seperti biasanya atau tidak mendapatkan perlakuan pembelajaran dengan pendekatan pendidikan matematika realistik (PMR) berbasis open-ended (saintifik).

Dalam mengumpulkan data kemampuan pemecahan masalah menggunakan metode tes yaitu tes esai dengan jumlah soal open ended sebanyak 10. Dari 10 soal tersebut memuat indikator penyelesaian masalah menggunakan aspek kemampuan pemecahan masalah. Kemampuan pemecahan ini dapat diukur melalui tes yang terbatas pada tes kemampuan pemecahan masalah kognitif matematika. Tes terdiri atas 10 soal uraian yang setiap soal menggunakan rubrik skor dengan nilai maksimal tiap soal yaitu 10 . Setiap masing-masing soal cerita mengandung ke-4 indikator yang dinilai yakni: memahami masalah, membuat rencana penyelesaian masalah, melaksanakan rencana penyelesaian masalah, dan melihat kembali penyelesaian. Pemberian post test merupakan teknik pengumpulan data tentang kemampuan pemecahan masalah matematika siswa kelas V SD Gugus V Kecamatan Buleleng. Tes dilakukan pada akhir pembelajaran yang bertujuan untuk mengukur kemampuan siswa. Tes tersebut kemudian diuji coba lapangan untuk mencari validitas, reabilitas, taraf kesukaran dan daya bedanya. Dalam uji validitas isi digunakan uji Gregory, kemudian untuk uji internal konsistensi butir menggunakan rumus product moment karena tes bersifat politomi. Tes hasil uji coba akan diberikan kepada siswa kelas eksperimen dan kontrol.

Metode analisis data dalam penelitian ini menggunakan metode analisis statistik deskriptif dan statistik inferensial. Statistik deskriptif dilakukan untuk mengetahui tinggi rendahnya kemampuan pemecahan masalah kelompok ekperimen dan kontrol nilai rata-rata (mean) tiap-tiap variabel dikonversikan dengan menggunakan kriteria rata-rata ideal dan standar deviasi. Analisis deskriptif dilakukan terhadap nilai rata-rata (mean), median, dan modus, dan varians dari hasil post test kelompok kontrol maupun kelompok eksperimen. Statistik inferensial analisis data peneliti menggunakan uji normalitas, uji homogenitas dan uji hipotesis (uji-t separated varians). Uji Normalitas sebaran data di dalam penelitian dapat dilakukan untuk meyakinkan bahwa di dalam sampel benar-benar berasal dari populasi yang memiliki data beristribusi normal sehingga uji hipotesis tersebut dapat dilakukan. Uji normalitas dalam penelitian dapat dikerjakan secara manual dengan analisis Chi-Khuadrat. Hasil yang didapat kemudian dibandingkan $x^{2}$ hitung dan juga nilai $x^{2}$ tabel pada (taraf signifikansi 5\%), Jika $x^{2}$ hitung $<x^{2}$ tabel, maka $\mathrm{H}_{0}$ diterima, maka sampel berasal dari populasi yang berdistribusi normal (Dantes, 2017). Uji Homogenitas Varians yakni uji kesamaan dua varians digunakan untuk menguji dan juga membandingkan antara varians terbesar dan terkecil. Jika data kelompok telah berdistribusi normal, maka uji homogenitas dapat dilakukan. Selanjutnya $F$ hitung dibandingkan dengan $F$ tabel pada taraf signifikansi 5\%. Jika hasil dari pengujian data mendapat hasil $\mathrm{F}_{\text {hitung }}<\mathrm{F}_{\text {tabel }}$ maka sampel homogen. 
Selanjutnya dilakukan pengujian hipotesis penelitian. Uji-t digunakan sebagai uji hipotesis penelitian ini. Bila jumlah anggota sampel sama $\mathrm{n}_{1}=\mathrm{n}_{2}$ dan varians homogen diuji dengan rumus separated varians. Adapun nilai hipotesis yang digunakan adalah $\mathrm{H}_{0}$ diterima ketika ( $\mathrm{t}_{\text {-hitung }} \leq \mathrm{t}_{\text {-tabel }}$ ), dan $\mathrm{H}_{0}$ ditolak jika $\mathrm{t}_{\text {-hitung }}$ lebih besar dari $t_{\text {-tabel }}\left(\mathrm{t}_{\text {-hitung }}>\mathrm{t}_{\text {-tabel }}\right)$.

\section{Hasil dan pembahasan}

Data yang dianalisis pada penelitian ini adalah Kemampuan Pemecahan Masalah Matematika siswa kelas V pada kelompok eksperimen dan kelompok kontrol. Data Kemampuan Pemecahan Masalah Matematika didapat atau diperoleh dari hasil post test yang telah diberikan pada akhir penelitian. Analisis data dilakukan pada masing-masing kelas yakni kelas eksperimen maupun kelas kontrol. Adapun hasil analisis data statistik deskriptif dijabarkan pada Tabel 2.

Tabel 2. Analisis Data dengan Statistik Deskriptif

\begin{tabular}{ccc}
\hline \multirow{2}{*}{ Statistik } & \multicolumn{2}{c}{ Hasil Kemampuan Pemecahan Masalah } \\
\cline { 2 - 3 } & Eksperimen & Kontrol \\
\hline Skor maksimal & 95 & 58 \\
Skor minimal & 60 & 23 \\
Mean & 79,78 & 41,34 \\
Modus & 80,93 & 44,1 \\
Median & 80,5 & 42,64 \\
Varians & 103,63 & 105,49 \\
\hline
\end{tabular}

Dari hasil analisis tabel di atas, dapat dideskripsikan bahwa data kemampuan pemecahan masalah matematika kelompok eksperimen, yaitu: mean $=79,78$; modus $=80,93$; median $=80,5$ dan varian $\left(\mathrm{s}^{2}\right)=$ 103,63. Sedangkan data kemampuan pemecahan masalah matematika kelompok kontrol, yaitu: mean = 41,34; modus $=44,1 ;$ median $=42,64$. Skor maksimal kelompok ekperimen dan kelompok kontrol adalah 95 dan 58 sedangkan skor minimal kelompok eksperimen dan kelompok kontrol adalah 60 dan 23 . Untuk melihat kecenderungan skor yang diperoleh siswa, maka data post test kemampuan pemecahan masalah matematika kelompok eksperimen disajikan ke dalam histogram sebagaimana terlihat pada Gambar 01.

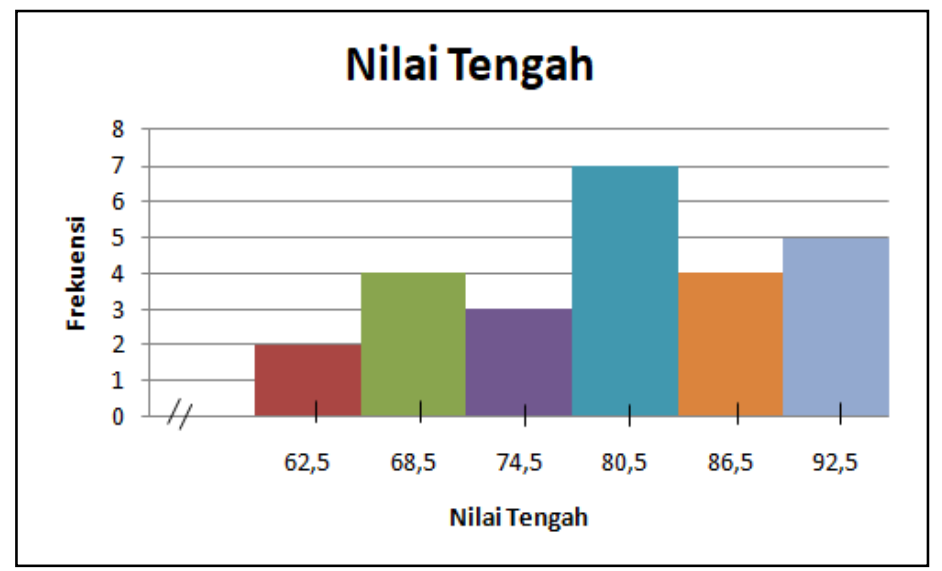

\section{Gambar 01}

Histogram Skor Kemampuan Pemecahan Masalah Matematika Kelas Eksperimen

Untuk mengetahui kualitas variabel kemampuan pemecahan masalah matematika pada kelas eksperimen digunakan kriteria penilaian skala lima Berdasarkan hasil konversi ke dalam kriteria penilaian skala lima, dapat dinyatakan bahwa kelompok eksperimen memiliki nilai rata-rata $\mathrm{M}=79,78$ yang berada pada rentangan 75,00 $\leq \overline{\mathrm{X}} \leq 100$ dengan kategori "Sangat tinggi".

Pada kelompok kontrol dapat dideskripsikan dari data kemampuan pemecahan masalah matematika kelompok kontrol, yaitu: mean $=41,34$; modus $=44,1$; median $=42,64$ dan varian $\left(\mathrm{s}^{2}\right)=$ 105,49 . Kecenderungan skor yang diperoleh siswa, kelompok kontrol disajikan ke dalam histogram sebagaimana terlihat pada Gambar 2. 


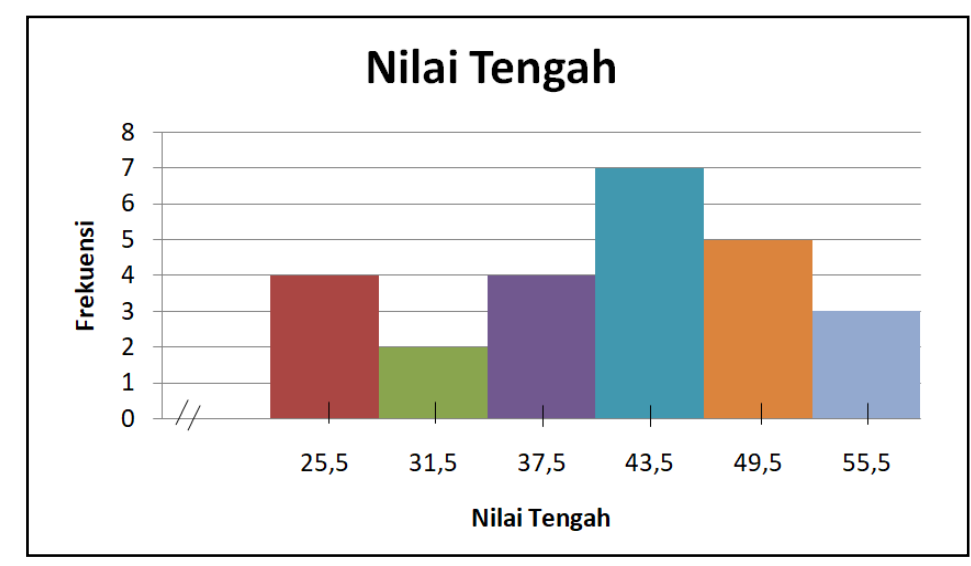

Gambar 02

Histogram Skor Kemampuan Pemecahan Masalah Matematika Kelas Kontrol

Untuk mengetahui kualitas variabel kemampuan pemecahan masalah matematika pada kelas kontrol digunakan kriteria penilaian skala lima. Berdasarkan hasil konversi ke dalam kriteria penilaian skala lima, dapat dinyatakan bahwa rata-rata kemampuan pemecahan masalah matematika kelompok kontrol adalah $\mathrm{M}=41,34$ yang berada pada rentangan 41,66 $\leq \overline{\mathrm{X}} \leq 58,34$ dengan kategori "Rendah".

Dari hasil post test didapatkan bahwa skor rata-rata hasil tes kemampuan pemecahan masalah kelompok eksperimen lebih tinggi dibandingkan kelompok kontrol. Rata-rata hitung hasil post test kelompok eksperimen adalah 79,78. Sedangkan kelompok kontrol cenderung lebih rendah dengan ratarata hitung 41,34 .

Sebelum melakukan uji hipotesis, maka hasil post test harus dilakukan beberapa uji prasyarat yang meliputi uji normalitas sebaran data dan uji homogenitas varians.

Uji normalitas sebaran data dilakukan pada kelompok eksperimen dan kelompok kontrol. Uji normalitas sebaran data diuji dengan menggunakan rumus Chi Kuadrat. Di bawah ini disajikan hasil uji normalitas kemampuan pemecahan masalah matematika siswa.

Tabel 03. Hasil Uji Normalitas Kemampuan Pemecahan Masalah

\begin{tabular}{|c|c|c|c|c|}
\hline No & Kelompok Data & $\mathbf{X}^{2}$ hitung & $\begin{array}{c}\mathrm{X}^{2} \text { tabel } \\
\text { (taraf sig. 5\%) }\end{array}$ & Keterangan \\
\hline 1 & Eksperimen & 3,521 & 7,815 & Normal \\
\hline 2 & Kontrol & 4,531 & 7,815 & Normal \\
\hline
\end{tabular}

Berdasarkan tabel 3, diperoleh $x^{2}$ hitung hasil post test kelompok eksperimen adalah 3,521 dan $x^{2}$ tabel 7,815 (taraf signifikansi 5\% dengan dk = $6-2-1=3$ ). Hal ini berarti $x^{2}$ hitung $(3,521)<x^{2}$ tabel $(7,815)$, maka dapat disimpulkan bahwa data hasil penelitian tersebut berdistribusi normal. Berikutnya $x^{2}$ hitung hasil post test kelompok kontrol adalah 4,531 dan $x^{2}$ tabel 7,815. Hal ini berarti $x^{2}$ hitung $(4,531)<$ $x^{2}$ tabel $(7,815)$, maka dapat disimpulkan bahwa data hasil penelitian tersebut berdistribusi normal.

Kemudian dilakukan uji homogenitas varians untuk mengetahui data dari kelompok eksperimen dan kontrol berdistribusi homogen atau tidak. Hasil pengujian homogenitas varians dengan Uji F disajikan pada tabel 04 berikut.

Tabel 04. Hasil Uji Homogenitas Varians

\begin{tabular}{ccccc}
\hline Kelompok Data & Varians & $\mathbf{F}_{\text {hitung }}$ & $\mathbf{F}_{\text {tabel }}$ & Keterangan \\
\hline $\begin{array}{c}\text { Eksperimen } \\
\text { Kontrol }\end{array}$ & 103,63 & 1,02 & \multirow{2}{*}{1,96} & Homogen \\
\hline
\end{tabular}

Dari hasil perhitungan didapat $F_{\text {hitung }}$ sebesar 1,02 dan $F_{\text {tabel }}$ sebesar 1,96 dengan $\mathrm{df}_{\text {pembilang }}=25-1$ $=24$ dan $\mathrm{df}_{\text {penyebut }}=25-1=24$, pada taraf signifikansi $5 \%$ adalah 1,96 . Hal tersebut menunjukkan bahwa 
nilai $F_{\text {hitung }}(1,02)<F_{\text {tabel }}(1,96)$. Sehingga, dapat disimpulkan berarti kelompok eksperimen dan kelompok kontrol memiliki varians yang homogen.

Setelah melakukan analisis deskripsi dan uji prasyarat, dilanjutkan dengan uji hipotesis untuk mengetahui pengaruh pendekatan Pendidikan Matematika Realistik berbasis open ended. Pengujian hipotesis $\mathrm{H}_{0}$ dan $\mathrm{H}_{1}$ dilakukan dengan cara analisis uji-t. Jumlah sampel di kelompok eksperimen dan kontrol sama $\left(\mathrm{n}_{1}=\mathrm{n}_{2}\right)$, sehingga menggunakan rumus seprated varians. Kriteria hipotesis yang digunakan adalah $\mathrm{H}_{0}$ diterima jika $\mathrm{t}_{\text {-hitung }}$ lebih kecil atau sama dengan $\mathrm{t}_{\text {-tabel }}\left(\mathrm{t}_{\text {-hitung }} \leq \mathrm{t}_{\text {-tabel }}\right)$, dan $\mathrm{H}_{0}$ ditolak jika $\mathrm{t}_{\text {-hitung }}$ lebih besar dari $t_{\text {tabel }}\left(t_{\text {-hitung }}>t_{\text {tabel }}\right)$ dengan $d k=n_{1}+n_{2}-2$.

Tabel 05. Hasil Uji Hipotesis

\begin{tabular}{ccccccc}
\hline Kelompok & $\mathrm{N}$ & $\bar{X}$ & $s^{2}$ & $\mathrm{t}_{\text {hitung }}$ & $\mathrm{t}_{\text {tabel }}$ & Kesimpulan \\
\hline Kelompok Eksperimen & 25 & 79,78 & 103,63 & \multirow{2}{*}{13,30} & \multirow{2}{*}{1,68} & $\mathrm{H}_{1}$ diterima \\
Kelompok Kontrol & 25 & 41,34 & 105,49 & & & $\mathrm{H}_{0}$ ditolak \\
\hline
\end{tabular}

Berdasarkan hasil perhitungan tabel 5 , didapatkan $t_{\text {hitung }}$ sebesar 13,30, sedangkan $t_{\text {tabel }}$ dengan $\mathrm{dk} 48$ pada taraf signifikansi $5 \%$ adalah 1,68 . Hal ini berarti, $t_{\text {hitung }}$ lebih besar dari $t_{\text {tabel }}\left(t_{\text {hitung }}>t_{\text {tabel }}\right)$ sehingga $\mathrm{H}_{0}$ ditolak dan $\mathrm{H}_{1}$ diterima. Dengan demikian, dapat diinterpretasikan bahwa terdapat pengaruh yang signifikan implementasi pendekatan Pendidikan Matematika Realistik (PMR) berbasis open-ended terhadap kemampuan pemecahan masalah matematika pada siswa kelas V di Gugus V Kecamatan Buleleng Tahun Ajaran 2019/2020.

Berdasarkan hasil penelitian, dapat diketahui bahwa terdapat pengaruh yang signifikan kemampuan pemecahan masalah matematika antara kelompok siswa yang mengikuti pembelajaran menggunakan pendekatan pendidikan matematika realistik berbasis open ended dan kelompok siswa yang mengikuti pembelajaran tidak menggunakan pendekatan pendidikan matematika realistik berbasis open ended pada siswa kelas V di Gugus V Kecamatan Buleleng Tahun Pelajaran 2019/2020. Perbedaan hasil kemampuan pemecahan masalah matematika siswa yang signifikan pada kelas eksperimen dan kontrol disebabkan oleh perbedaan pemberian perlakuan yang diberikan pada kelas eksperimen dan kelas kontrol. Perbedaan tersebut telah terlihat pada saat kegiatan proses pembelajaran dilakukan. Perbedaan hasil kemampuan pemecahan masalah matematika pada kelas eksperimen dan kontrol juga dapat dilihat dari rata-rata skor kemampuan pemecahan masalah matematika pada kedua kelompok dan hasil dari uji-t.

Pertama, Pendekatan matematika realistik adalah pendekatan yang menempatkan realitas dan pengalaman perserta didik sebagai dasar awal dalam proses pembelajaran dimana siswa diberikan kesempatan untuk mengkontruks pengetahuannya sendiri melalui masalah yang ada di sekitarnya. (Evi, 2011). Pembelajaran matematika realistik memberikan kesempatan kepada siswa mempunyai kesempatan untuk menemukan kembali konsep matematika yang nantinya akan diaplikasikan untuk memecahkan masalah yang diberikan dalam kehidupan sehari-hari atau masalah dam bidang lain. Ada beberapa hal yang menunjukkan bahwa pendekatan Pendidikan Matematika Realistik berbasis open ended berpengaruh terhadap kemampuan pemecahan masalah matematika siswa. Pertama, kelompok eksperimen diperkenalkan dengan pembelajaran yang konstektual dan nyata. Permasalahan yang nyata dan sesuai dengan lingkungan dalam pembelajaran dapat membuat siswa memahami apa yang harus mereka kerjakan karena bersifat nyata. Kurniadi (dalam Lestari \& Sofyan, 2014), mengemukakan bahwa kelebihan PMR antara lain yakni: Pertama yaitu PMR berpendekatan dengan bertujuan untuk membangkitkan pemahamannya sendiri akan masalah, sehingga siswa akan lebih mengingat. Kedua, pembelajaran bersifat menyenangkan peserta didik sehingga siswa lebih mudah menemukan penyelesaian permasalahan tanpa ada rasa takut dengan menggunakan permasalahan nyata. Ketiga, pembelajaran membuat siswa turut aktif dan terbuka terhadap pemahamannya. Keempat, proses pembelajaran dapat memupuk kerjasama dalam kelompok. Kelima, pembelajaran menemukan sendiri sehingga siswa dapat mempresentasikan hasil penyelesaiannya sendiri dan lebih mengasah keberanian. Keenam, dapat melatih siswa dalam mengemukakan pendapatnya. Ketujuh, secara tidak langsung pembelajaran dapat mendidik budi pekerti siswa. Kelebihan PMR lainnya yakni melibatkan siswa, maka pembelajaran tidak lagi menganut paradigma transfer to knowledge, sehingga berpartisipasi dalam pembelajaran. Pembelajaran RME akan membuat proses belajar menjadi lebih bermakna. Hal tersebut sesuai dengan pendapat Liwis, dkk (2017), pembelajaran matematika realistik bahwa pembelajaran menekankan kebermaknaan yang mengaitkan aktivitas yang berkaitan dengan kehidupan nyata dan dekat dengan lingkungan anak dalam suatu pembelajaran dapat diperoleh melalui berbagai cara.

Selain itu, pembelajaran yang nyata dan sesuai dengan lingkungannya dapat memahami masalah dan belajar akan lebih aktif karena permasalahan berkaitan dengan kehidupannya yang ia hadapi 
sehingga pembelajaran menjadi lebih bermakna dan menarik. Pembelajaran tidak diawali dengan sifat, definisi, maupun aturan yang disertakan contoh-contoh penerapannya. Namun di awali pemberian masalah real. Siswa dapat diberikan bimbingan oleh guru namun bukan berarti siswa memperoleh cara penyelesaiannya. Hal ini dapat dikaitkan dengan paham kontruktivisme yang artinya seseorang yang ingin menemukan pengetahuan harus melakukan dan menemukan sendiri bukan hasil dari transfer ilmu. Kedua, di setiap pembelajaran, siswa mendapat kesempatan untuk memakai beberapa strategi penyelesaian/model untuk dapat menyelesaikan soal yang dihadapi sesuai pengetahuan yang dimiliki sebelumnya dan melatih kemampuan pemecahan masalah matematika. Menurut Wijaya (2012) kegiatan seperti diskusi, berargumen, memberikan saran atau penjelasan, dapat mengkomunikasikan proses pemecahan suatu masalah menggunakan bahasa matematika. Dalam hal ini, ketika siswa mendapat kesempatan untuk memakai beberapa strategi perencanaan siswa dapat menghubungkan antara pengetahuan yang telah dimiliki dengan permasalahan yang didapatkan. Ketiga, masalah yang disajikan dalam bentuk open ended (masalah terbuka). Masalah terbuka akan memberi kesempatan bagi siswa agar mengenali berbagai strategi atau banyak solusi/penyelesaian sesuai dengan pengetahuannya. Selain itu, penggunaan masalah terbuka dalam pembelajaran mampu menumbuhkan kemampuan pemecahan masalah siswa. Penggunaan open ended dapat menggali kemampuan dan pemahaman yang ada pada diri siswa. Ketika pembelajaran menggunakan open ended maka siswa memiliki cara memperoleh jawaban benar dengan mengandung berbagai cara penyelesaian yang tepat.

Hasil penelitian ini didukung oleh penelitian yang telah dilakukan oleh (Fitriani \& Maulana, 2016), bahwa Pendekatan matematika realistik dan pendekatan konvensional memberikan pengaruh yang berbeda terhadap kemampuan pemahaman matematis siswa. Pengaruh yang lebih baik terdapat di kelas eksperimen yang memperoleh pembelajaran dengan menggunakan pendekatan matematika realistik. Dari penelitian yang telah dilakukan bahwa kelas eksperimen memiliki nilai yang lebih tinggi dibandingkan hasil yang didapatkan dari kelas kontrol. Penelitian dari Agus, Desak, dan Sujendra, 2018) menyatakan bahwa pembelajaran menggunakan pendekatan PMRI berbasis open-ended menunjukkan efektivitas tinggi dan terdapat perbedaan kemampuan berpikir kreatif matematika antara kelompok siswa yang mengikuti pembelajaran menggunakan pendekatan PMRI berbasis open-ended dan kelompok siswa yang mengikuti pembelajaran tidak menggunakan pendekatan PMRI berbasis open-ended. Pendapat dari Giny, M. Maulana, dan I. Isrok'atun (2017) pendekatan open-ended mempunyai pengaruh positif terhadap kemampuan pemecahan masalah matematis, hal tersebut dilihat dari peningkatan kemampuan pemecahan masalah matematika di kelas eksperimen dengan katagori sedang. Pembelajaran dengan open ended lebih baik dibandingkan dengan model konvensional. Menurut Danic, dkk. (2019), menyatakan bahwa terdapat perbedaan yang signifikan kemampuan pemecahan masalah matematika kelompok siswa yang mengikuti pembelajaran menggunakan pendekatan pembelajaran matematika realistik berbasis open-ended dan kelompok siswa yang mengikuti pembelajaran tidak menggunakan pendekatan pembelajaran matematika realistik berbasis open-ended. menurut Susiana, Sitinjak, dan Kimura (2019) menyatakan bahwa pendekatan matematika realistik yang dilakasanakan dengan baik dapat membangun kemampuan memecahkan masalah matemastis siswa, hal ini ditunjukkan dengan meningkatnya rata-rata indikator pemecahan masalah matematika di setiap siklus.

Kedua, Selanjutnya, berkenaan dengan rata-rata skor kemampuan pemecahan masalah Matematika kelompok siswa yang mengikuti pembelajaran tidak menggunakan pendekatan pendidikan matematika realistik berbasis open ended yang berada pada kategori sedang dipengaruhi oleh beberapa hal berikut. Pada pembelajaran di kelas lebih banyak dilakukan penyampaian materi oleh guru. Guru secara langsung mengajarkan materi/rumus-rumus matematika dan dilanjutkan dengan latihan soal-soal tanpa memberi siswa kesempatan bertanya dan menjawab masing-masing. Hal tersebut mengakibatkan siswa tidak dapat menggali kemampuan pemecahan masalahnya, sehingga rumus dan soal-soal langsung diberikan dan siswa hanya mencatat. Pembelajaran dengan pemecahan masalah menghendaki siswa belajar lebih aktif, bukan guru yang lebih aktif dalam pembelajaran sehingga dapat menumbuhkan sikap kreatif seperti mencari sendiri, menemukan, merumuskan, dan menyimpulkan sendiri (Susanto, 2013). Pembelajaran masih terpaku oleh guru dan pemberian materi hanya pada buku paket. Guru belum mampu mengembangkan materi/permasalahan yang terdapat dalam buku paket menjadi masalah yang kontekstual. Dalam pembelajaran ini siswa lebih banyak mendengarkan penjelasan guru di depan kelas, kemudian guru memberikan tugas yaitu mengerjakan soal yang ada di buku paket. Hal tersebut mengakibatkan pembelajaran tidak bermakna hanya berifat hafalan dan tidak ada pemahaman konsep sehingga siswa tidak mampu dalam memahami dan memecahkan masalah matematika. Sejalan menurut Skemp (dalam Mairing, 2018), yang menyatakan suatu konsep yang bermakna akan lebih lama bertahan di dalam pikiran siswa. Sebaliknya, yang tidak bermakna akan lebih mudah dan cepat dilupakan 
oleh seorang siswa. Sehingga, dalam permasalahan matematika dituntut agar seorang siswa dapat melakukan pengaitan antar konsep matematis sehingga konsep-konsep tersebut bermakna dalam pikiran siswa. Sehingga apabila siswa diberikan soal nonrutin siswa mengalami kesulitan memecahkan masalah.

Proses belajar dengan menggunakan pendekatan Pendidikan Matematika Berbasis Open Ended yang diterapkan pada kelompok eksperimen dan pembelajaran konvensional pada kelompok kontrol di Gugus V Kecamatan Buleleng, pada penelitian ini menunjukkan bahwa terdapat perbedaan pada kemampuan pemecahan masalah matematika siswa. Hal ini dapat dilihat dari data hasil kemampuan pemecahan masalah matematika siswa. Secara deskriptif, kemampuan pemecahan masalah matematika siswa pada kelompok eksperimen lebih tinggi dibandingkan dengan kelompok kontrol.

\section{Simpulan dan saran}

Berdasarkan hasil penelitian dan juga pembahasan, dapat disimpulkan bahwa Kemampuan Pemecahan Masalah Matematika siswa yang dibelajarkan dengan pendekatan Pendidikan Matematika Berbasis Open Ended memiliki pengaruh yang signifikan dengan rata-rata hitung hasil post test adalah 79,78. Berbeda dengan Kemampuan Pemecahan Masalah Matematika siswa yang dibelajarkan dengan pembelajaran konvensional atau sesuaipembelajaran disekolah cenderung lebih rendah dengan rata-rata hitung 41,34.

Hasil uji hipotesis menggunakan Uji-T dengan rumus separated varians didapatkan nilai $t_{\text {hitung }}$ sebesar 13,30, sedangkan $t_{\text {tabel }}$ dengan dk 48 pada taraf signifikansi $5 \%$ adalah 1,68 . Hal ini berarti, $t_{\text {hitung }}$ lebih besar dari $t_{\text {tabel }}\left(t_{\text {hitung }}>t_{\text {tabel }}\right)$. Hal tersebut berarti $\mathrm{H}_{0}$ ditolak dan $\mathrm{H}_{1}$ diterima. Dengan demikian, dapat dinyatakan bahwa terdapat pengaruh yang signifikan implementasi pendekatan Pendidikan Matematika Realistik (PMR) berbasis open-ended terhadap kemampuan pemecahan masalah matematika pada siswa kelas V di Gugus V Kecamatan Buleleng Tahun Ajaran 2019/2020.

Dengan demikian, pendekatan pendidikan matematika realistik berbasis open ended berpengaruh terhadap kemampuan pemecahan masalah Matematika siswa kelas V SD di Gugus V Kecamatan Buleleng Tahun Ajaran 2019/2020. Berdasarkan simpulan dari penelitian yang telah dilakukan dapat, maka dapat diajukan beberapa saran sebagai tindak lanjut dari penelitian ini. Saran ini ditujukan kepada berbagai pihak yang terkait dengan manfaat penelitian sebagai berikut. Kepada Siswa disarankan untuk siswa, agar di dalam proses pembelajaran bisa menghubungkan hal nyata dengan konsep matematika melalui pendekatan pendekatan pendidikan matematika realistik berbasis open ended dan menjadi lebih menggali pemahaman saat proses belajar berlangsung, serta mampu meningkatkan kemampuan pemecahan masalah matematika khususnya pada mata pelajaran matematika. Siswa juga harus melatih kemampuannya memahami soal dan mampu memecahkan masalah dengan kemampuannya. Kepada Guru agar mampu menciptakan suasana pembelajaran yang baru dan menarik bagi siswa serta lebih inovatif seperti penerapan pembelajaran yang menggunakan masalah kontekstual yang realistik dan juga berbasis open ended dan dengan didukung media pembelajaran yang relevan untuk dapat meningkatkan kemampuan pemecahan masalah matematika. Guru juga dapat memberikan kepada peserta didik soal open ended, sehingga guru tidak hanya monoton memberikan soal hanya pada buku paket saja. Kepada Kepala Sekolah agar hasil penelitian ini digunakan sebagai acuan dalam meningkatkan kemampuan pemecahan masalah matematika siswa dan memotivasi guru-guru untuk menerapkan pendekatan Pendidikan Matematika Realistik berbasis open ended karena pembelajaran ini dapat meningkatkan kemampuan pemecahan masalah matematika sehingga mengingkatkan hasil belajar siswa, khususnya dalam mata pelajaran matematika serta mata pelajaran lain pada umumnya. Kepada Peneliti Lain disarankan yang berminat mengadakan penelitian lebih lanjut mengenai pendekatan Pendidikan Matematika Realistik berbasis open ended hendaknya mengetahui kendala-kendala yang dimiliki sebagai pertimbangan untuk penyempurnaan dan perbaikan penelitian yang dilakukan dan dapat menambah variabel penelitian untuk penyempurnaan penelitian yang akan dilaksanakan.

\section{Daftar Rujukan}

Agus, Kadek Alit Dwipayana, Desak Putu Parmiti dan Komang Sujendra Diputra.2018. Pengaruh Pendekatan Pendidikan Matematika Realistik Berbasis Open Ended Terhadap Kemampuan Berpikir Siswa SD Kelas V. Journal of Education Technology. Vol. 2 (3) pp. 87-94. https://ejournal.undiksha.ac.id/index.php/JET/article/view/16380/9801

Amir, M. F. (2015). Pengaruh Pembelajaran Kontekstual Terhadap Kemampuan Pemecahan Masalah Matematika Siswa Sekolah Dasar. In Prosiding Seminar Nasional Pendidikan, (2011), 34-42. 
Antara, P. A. (2019). Implementasi Pengembangan Karakter Anak Usia Dini Dengan Pendekatan Holistik. Jurnal Ilmiah VISI PGTK PAUD Dan Dikmas, 14(1), 17-26.

Danic, I., Japa, I. G. N., \& Diputra, K. S. (2019). Penguatan Kemampuan Pemecahan Masalah Matematika Siswa Melalui Pembelajaran Matematika Realistik Berbasis Open-Ended. Jurnal Ilmiah Pendidikan Citra Bakti, 6, 9-22. https://doi.org/10.1017/CB09781107415324.004

Giny Nuraeni Husniah, M. Maulana, dan I. Isrok'atun. 2017. Pengaruh Pendekatan Open-Ended Terhadap Kemampuan Pemecahan Masalah Matematis dan Motivasi Belajar. Jurnal Pena ilmiah Vol. 2 No. 1. https://ejournal.upi.edu/index.php/penailmiah/article/view/11220/6842

Dantes, N. (2012). Metode Penelitian (C. A. Offset, ed.). Yogyakarta.

Dantes, N. (2017). Desain Eksperimen dan Analisis Data. Depok: Rajawali Pers.

Fitriani, K., \& Maulana. (2016). Masalah Matematis Siswa Sd Kelas V Melalui Pendekatan. 3(1), 40-52. https://doi.org/10.17509/mimbar-sd.v3i1.2355

Gunantara, G., Suarjana, M., \& Riastini, P. N. (2014). Penerapan Model Pembelajaran Problem Based Learning Untuk Meningkatkan Kemampuan Pemecahan Masalah Siswa Kelas V. Jurnal Mimbar PGSD Universitas Pendidikan Ganesha, 2(1).

Hadi, S. (2017). Pendidikan Matematika Realistik: Teori, Pengembangan, dan Implementasinya. Jakarta: Rajawali Pers.

Hartono, Y. (2014). Matematika: Strategi Pemecahan Masalah. Yogyakarta: Graha Ilmu.

Hidayat, W., \& Sariningsih, R. (2018). Kemampuan Pemecahan Masalah Matematis Dan Adversity Quotient Siswa SMP Melalui Pembelajaran Open Ended. Jurnal Nasional Pendidikan Matematika, 2(1), 109118.

Isrok'atun, \& Rosmala, A. (2018). Model-model Pembelajaran Matematika. Jakarta: PT. Bumi Aksara.

Juseria, Susiana Tambunan, Debora Suryani Sitinjak, dan Kimura Patar Tamba.2019. Pendekatan

Matematika Realistik untuk Membangun Kemampuan Pemecahan Masalah Matematis Siswa Kelas XI IPS pada Materi Peluang. JOHME: Journal of Holistic Mathematics Education Vol 2, No 2 June 2019 pages: 119 - 130. https://ojs.uph.edu/index.php/JOHME/article/view/1691/pdf

Kamarullah. (2017). Pendidikan Matematika Di Sekolah Kita. Al Khawarizmi: Jurnal Pendidikan Dan Pembelajaran Matematika, 1(1), 21-32.

Lestari, L., \& Sofyan, D. (2014). Perbandingan Kemampuan Pemecahan Masalah Siswa Dalam Matematika Antara yang Mendapat Pembelajaran Matematika Realistik (PMR) dengan Pembelajaran Konvensional. Jurnal Pendidikan Matematika, 3(2), 95-108.

Liwis, N., Antara, P. A., \& Ujianti, P. R. (2017). Pengaruh Model Pembelajaran Matematika Realistik Terhadap Kemampuan Mengenal Konsep Bilangan Pada Anak Kelompok A Taman Kanak-Kanak Gugus V Kecamatan Buleleng. E-Journal Pendidikan Anak Usia Dini, 5(1), 116-126.

Mairing, J. P. (2018). Pemecahan Masalah Matematika: Cara Siswa Memperoleh Jalan untuk Berpikir dan Sikap Positif. Bandung: Alfabeta.

Muchlis, E. E. (2012). Pengaruh Pendekatan Pendidikan Matematika Realistik Indonesia (PMRI) terhadap Perkembangan Kemampuan Pemecahan Masalah Siswa Kelas II SD Kartika 1 . 10 Padang. Jurnal Exacta, $X(2), 136-139$.

Sa'o, S. (2016). Berpikir Intuitif sebagai Solusi Mengatasi Rendahnya Prestasi Belajar Matematika. Jurnal Review Pembelajaran Matematika, 1(1), 43-56. https://doi.org/10.15642/jrpm.2016.1.1.43-56

Soviawati, Evi.2011. Pendekatan Matematika Realistik (PMR) untuk Meningkatkan Kemampuan Berfikir Siswa Di Tingkat Sekolah Dasar. Edisi Khusus No. 2, Agustus 2011. http://jurnal.upi.edu/file/9Evi_Soviawati-edit.pdf

Sugiyono. (2017). Statistika Untuk Penelitian. Bandung: Alfabeta.

Susanto, A. (2013). Teori Belajar dan Pembelajaran di Sekolah Dasar (1st ed.). Jakarta: Kencana Prenadamedia Group. 
Wibowo, A. (2017). Pengaruh Pendekatan Pembelajaran Matematika Realistik dan Saintifik terhadap Prestasi Belajar , Kemampuan Penalaran Matematis dan Minat Belajar The Effect of Teaching Realistic and Scientific Mathematics Approach on Students Learning Achievement, Mathema. 4(1), 1-10.

Wijaya, A. (2012). Pendidikan Matematika Realistik; Suatu Alternatif Pendekatan Pembelajaran Matematika. Yogyakarta: Graha Ilmu. 